\title{
The effects of magnesium pemoline, caffeine and picrotoxin on a food reinforced discrimination task'
}

BARRETT R. COOPER, W. JOSEPH POTTS, ${ }^{2}$ DAVID L. MORSE, ${ }^{3}$ and WILLIAM C. BLACK, Purdue University, Laffayette, Ind. 47907

The effects of several doses of magnesium pemoline, caffeine, and picrotoxin on the acquisition of a foodreinforced light-dark discrimination task in the T-maze were compared. Both magnesium pemoline and caffeine facilitated the acquisition of the task at appropriate doses. The picrotoxin-treated animals were incapacitated except at the lowest dose administered.

Magnesium pemoline has been shown to facilitate the acquisition of tasks motivated by both positive and negative reinforcement (Lubar et al, 1967; Kulkarni, 1967). Although magnesium pemoline is known to be a mild central nervous system (CNS) stimulant, several studies have shown that it also augments RNA polymerase production (Glasky \& Simon, 1966; Simon \& Glasky, 1968). Behavioral evidence supporting the view that magnesium pemoline's mechanism of action is not simply that of a mild CNS stimulant was provided by Plotnikoff (1966). He demonstrated magnesium pemoline facilitated acquisition of a jump-out avoidance while methamphetamine did not. Morris et al (1967) showed magnesium pemoline had no effect on RNA either in vivo or in vitro. Others have reported the behavioral effects of the drug are due only to CNS stimulant activity (Frey \& Polidora, 1967; Beach \& Kimble, 1967; Potts, 1968).

While a number of studies claim to have shown that magnesium pemoline's effect can be explained by CNS stimulation, only two published studies have compared magnesium pemoline and other CNS stimulants on the same task. Both studies utilized escape-avoidance paradigms. Plotnikoff (1966) found magnesium pemoline superior to methamphetamine and vehicle control groups in facilitating the acquisition of a jump-out avoidance task. Filby et al (1967) found that both magnesium pemoline and d-amphetamine enhanced the acquisition of a discriminated avoidance response; however, the magnesium pemoline treated group displayed fewer intertrial interval responses. When compared to CNS stimulants, the magnesium pemoline treated animals have shown superior acquisition of an avoidance response.

Comparisons of magnesium pemoline to other CNS stimulants on tasks utilizing positive reinforcement have not been reported. The present experiment was conducted to provide evidence concerning the effects of magnesium pemoline, caffeine, and picrotoxin on the acquisition of a positively reinforced light-dark discrimination in the T-maze.

\section{METHOD}

Forty-five naive male hooded rats raised and maintained under continuous light conditions were food deprived to $80 \%$ of their ad lib body weight and randomly assigned to 1 of 15 treatment conditions. All animals were between 110 and 130 days of age at the time of testing.

The apparatus consisted of a T-maze constructed of 3/8-in. plywood painted flat gray with a clear Plexiglas top and a grid floor throughout. The width of all the compartments was 6 in. and the depth from the grid floor to the top of the maze was 5 in. The startbox was $8 \mathrm{in}$. long and separated from the main alley of the maze by a guillotine door. The runway and arms of the maze were each 12 in. long. Lights $(15 \mathrm{~W})$ positioned behind translucent Plexiglas at each end of the runways served as the discriminanda for the task.
All drugs were suspended in a $0.3 \%$ tragacanth vehicle. Each $S$ received an intraperitoneal (i.p.) injection of $5,10,15$, or $20 \mathrm{mg} / \mathrm{kg}$ magnesium pemoline; $1,3,5$, or $7 \mathrm{mg} / \mathrm{kg}$ caffeine: $0.25,0.50,0.75$, or $1.00 \mathrm{mg} / \mathrm{kg}$ picrotoxin; or an equated volume of the vehicle. The $S$ was then returned to the home cage and introduced into the maze 30 min later. Two minutes were allowed for adaptation after the animal was placed in the startbox.

All testing was done in a darkened room. The correct side was alternated from the left to the right arm of the T-maze according to a modified Gellerman sequence. As previous work done with rats from our colony raised under constant light conditions demonstrated that they had a distinct preference for the lighted arm of the maze (Potts, 1968), the darkened goal arm served as the correct stimulus. An incorrect trial was scored when the $S$ placed both forepaws into the incorrect arm of the maze. As a correction procedure was used, every trial ended with a reinforcement which consisted of a 45-mg Noyes food pellet. A testing session terminated either when an animal performed to a criterion of nine correct responses in 10 trials or a $S$ spent $15 \mathrm{~min}$ without consuming a pellet after leaving the startbox on any given trial.

\section{RESULTS AND DISCUSSION}

The animals treated with $1.0 \mathrm{mg} / \mathrm{kg}$ caffeine reached the $9 / 10$ criterion in significantly fewer trials than the control group $(F=4.66, \quad \mathrm{df}=3 / 8, \mathrm{p}<.05)$, and the $10 \mathrm{mg} / \mathrm{kg}$ magnesium pemoline group also reached criterion in significantly fewer trials than the control group $(F=5.35$, $\mathrm{df}=3 / 8, \mathrm{p}<.05$ ). Animals treated at other dosage levels for both drugs did not differ from the control groups (Fig. 1).

None of the picrotoxin-treated animals dosed with $0.50 \mathrm{mg} / \mathrm{kg}$ or greater completed the task because they failed to consume the food pellet within the allotted 15 -min interval

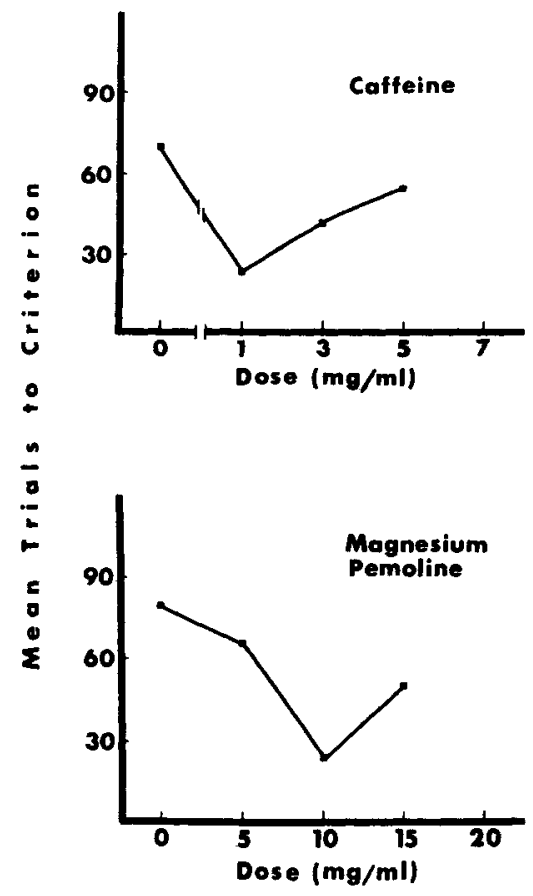

Fig. 1. The effects of various dosage treatments of caffeine and magnesium pemoline on the acquisition of a light-dark discrimination. 
after leaving the startbox. The animals treated with $7 \mathrm{mg} / \mathrm{kg}$ caffeine and $20 \mathrm{mg} / \mathrm{kg}$ magnesium pemoline were also unable to complete the task in the allotted time.

These results suggest that magnesium pemoline's effect is not different from that of a CNS stimulant (caffeine) and both can facilitate the acquisition of a positively reinforced discrimination. The dose response effects for both drugs were nonlinear, showing an optimal dose for the facilitation of acquisition in our apparatus.

The failure of the picrotoxin-treated animals to run in the T-maze is at present unexplainable. Pretrial injections of the drug have been used successfully in an appetitive maze learning situation (Prien et al, 1963). McGaugh (1967) has stated that the effect of a given drug on learning varies with the drug dose, age, apparatus, strain, and sex of the animals used.

While several possible mechanisms such as stimulus reactivity (Beach \& Kimble, 1967) or stimulant-enhanced consolidation (McGaugh, 1967) may explain the magnesium pemoline and caffeine data, more information of a comparative nature concerning the effects of both analeptics and RNA enhancers on learning is necessary.

\section{REFERENCES}

BEACH, G., \& KIMBLE, D. Activity and responsivity in rats after magnesium pemoline injections. Science, 1967, 155, 698-701.

FILBY, Y., SZARA, S., \& SALZMAN, B. Magnesium pemoline: Effect on acquisition and retention of discriminated avoidance behavior. Psychonomic Science, 1967, 9, 131-132.
FREY, P., \& POLIDORA, V. Magnesium pemoline: Effect on avoidance conditioning in rats. Science, 1967, 155, 1281-1282.

GLASKY, A., \& SIMON, L. Magnesium pemoline: Enhancement of brain RNA polymerases. Science, 1966, 151, 702-703.

KULKARNI, A. Magnesium pemoline: Facilitation of instrumental avoidance learning. Psychonomic Science, 1967, 9, 39-40.

LUBAR, J., BOITANO, J., GUROWITZ, E., \& AIN, B. Enhancement of performance in the Hebb-Williams maze by magnesium pemoline. Psychonomic Science, 1967, 7, 381-382.

McGAUGH, J. Drug facilitation of memory and learning. Paper presented at the Sixth Annual Meeting of the American College of Neuropsychopharmacology, San Juan, Puerto Rico, 1967.

MORRIS, N., AGHAJANIAN, G., \& BLOOM, F. Magnesium pemoline: Failure to affect in vivo synthesis of brain RNA. Science, 1967, 155, 1125-1126.

PLOTNIKOFF, N. Magnesium pemoline: Enhancement of learning and memory of a conditioned avoidance response. Science, 1966, 151, 703-704.

POTTS, W. J. An investigation of drug effects on learning and memory in rats. Unpublished doctoral dissertation, 1968.

PRIEN, R., WAGNER, M., \& KAHAN, S. Lack of facilitation in maze learning by picrotoxin and strychnine sulphate. American Journal of Phy siology, 1963, 204, 488-492.

SIMON, L., \& GLASKY, A. Magnesium pemoline: Enhancement of brain RNA synthesis in vivo. Life Sciences, 1968, 7, 197-202. NOTES

1. Supported in part by David Ross Grant PRF 5069, Purdue Research Foundation, and MH 14156-01, National Institute of Mental Health to W.C.B. W.J.P. and D.L.M. were National Institute of Mental Health predoctoral fellows, 1-F1-MH 30331 and 1-F1-MH 37435, respectively.

2. Present address: G. D. Searle Co., Chicago, Illinois.

3. Present address: State University of New York, New Paltz, New York.

\section{(Continued from page 224)}

motivated, performed for its own sake rather than for some extrinsic goal (Koch, 1956). However, potential "extrinsic" incentives were present, i.e., auditory reinforcement from clicks produced by passage through the photocells, visual stimulation, handling, return to home cage, and feeding 1-h later. It is unlikely that such incentives produced the behavior because none were contingent on running.

Others have reported well-maintained, nonrewarded running. Clark \& Miller (1966) found fast, nonrewarded running following rewarded runs in a $\mathrm{T}$-maze and attributed their finding to use of a very short intertrial interval. In Logan's study (1960) of "operant-level" running in an alley, rats, given one trial a day, never failed to run, but their running was quite slow. Logan attributed the maintenance of running without reward to use of a very long intertrial interval, food deprivation, and confinement in small cages. The procedural differences between the present study and those of Clark and Miller, and Logan are too great to permit a statement concerning the conditions necessary to produce continued, nonrewarded running.

A feature of the present research is that it permits a comparison of the same gross response under rewarded and nonrewarded conditions. First, nonrewarded running can be as fast as rewarded running. Nonrewarded running is faster with a large endbox than with a small one, possibly because the large endbox permits more "playful" behavior. Second, because speeds were depressed for a large number of trials following food reward, fast nonrewarded running is probably not a case of positive transfer from prior reward conditions to nonreward conditions. In the previously rewarded groups, the U-shaped function obtained on nonrewarded trials may reflect a change from "extrinsic" to "intrinsic" motivation. Third, speeds (and, from observation, the amount of "playful" behavior) on nonrewarded trials gradually increased, resembling an acquisition function obtained with reward, suggesting either the acquisition of $S-R$ connections or increased incentive value with repeated experience. Fourth, peak performance without reward required many more trials to achieve than with reward, indicating either that the reinforcement for nonrewarded running is weaker than food reward, or that "intrinsic" motivation develops quite gradually. Fifth, terminal nonrewarded performance was unaffected by the previous schedule of reward. Perhaps the variables regulating "intrinsically"-motivated behavior are not the same as those regulating "extrinsically"-motivated behavior.

\section{REFERENCES}

CLARK, J. W., \& MILLER, S. B. The development of rapid running in T-mazes in the absence of obvious rewards. Psychonomic Science, $1966,4,127-128$.

$\mathrm{KOCH}, \mathrm{S}$. Behavior as "intrinsically" regulated: Work notes towards a pre-theory of phenomena called "motivational." In M. R. Jones (Ed.), Nebraska symposium on motivation. Lincoln: University of Nebraska Press, 1956.

LOGAN, F. A. Incentive. New Haven: Yale University Press, 1960 NOTE

1. Based on a portion of a Ph.D. dissertation submitted to the Department of Psychology, University of Pittsburgh. The author expresses appreciation to J. Trevor Peirce for his guidance of the research. 